\title{
PENERAPAN METODE PAIRED READING/ PAIRED SUMMARIZING UNTUK MENINGKATKAN KEMAMPUAN PEMAHAMAN MEMBACA TEKS PADA SISWA SMK ABDURRAB PEKANBARU
}

\author{
Neni Triana \\ Universitas Abdurrab Pekanbaru, Riau \\ E-mail: neni.triana@univrab.ac.id
}

\begin{abstract}
The purpose of this research is to know the effect of using Paired Reading/ Paired Summarizing on reading in comprehension student at SMK Abdurrab Pekanbaru, especially in Health Analysis department. This research used quasi-experimental method with pretest-posttest control group design. The total sample was 64 students who were divided into two classes, as experimental and control class. In ready ability pre-test reading ability the result showed $68.8 \%$ students were in bad category from both experimental and control classes. After conducting an experiment using the Paired Reading / Paired Summarizing learning method with the same teaching material, 12 students (35.3\%) were obtained in the good category and 10 students $(29.4 \%)$ in the very good category from experimental class, while the control class contained only 4 students (11.8\%) and 2 students (5.9\%) with the same category. The research can be concluded that using Paired Reading/Paired Summarizing on occasional student of Abdurrab Pekanbaru can increase the reading comprehension of student ability.
\end{abstract}

Keywords: paired reading/paired summarizing; reading comprehension ability.

\begin{abstract}
ABSTRAK
Tujuan dari penelitian ini adalah untuk mengetahui efek dari menggunakan Paired Reading/ Paired Summarizing pada pemahaman membaca siswa di SMK Abdurrab Pekanbaru, khususnya pada jurusan Analisis Kesehatan. Jenis penelitian yang digunakan adalah eksperimen semu dengan pretest-posttest control group design. Total sampel adalah 64 siswa yang dibagi menjadi dua kelas yaitu eksperimen dan kontrol. Pada pre-test kemampuan membaca didapatkan hasil $68.8 \%$ dengan kategori buruk baik dikelas eksperimen maupun control. Setelah dilakukan percobaan dengan menerapkan metode pembelajaran Paired Reading/ Paired Summarizing dengan bahan ajar yang sama, diperoleh 12 siswa (35.3\%) pada kategori bagus dan 10 siswa (29.4\%) pada kategori sangat bagus di kelas eksperimen, sedangkan kelas kontrol hanya terdapat 4 siswa (11.8\%) dan 2 siswa $(5.9 \%)$ dengan kategori sama. Dari hasil penelitian ini dapat disimpulkan bahwa penggunaan metode Paired Reading/ Paired Summarizing pada pemahaman membaca siswa dapat meningkatkan kemampuan pemahaman membaca pada siswa.
\end{abstract}

Kata kunci: paired reading/ paired summarizing; kemampuan pemahaman membaca.

\section{PENDAHULUAN}

Di era milenial ini, banyak jenis informasi ditemukan dalam teks bahasa Inggris. Salah satu ketrampilan yang kini harus dikuasai adalah reading. Hal ini penting untuk mengejar perkembangan dunia di bidang ilmu dan teknologi, mengingat sebagian besar karya-karya ilmiah di bidang ilmu pengetahuan dan teknologi dirilis dalam bahasa Inggris. Bahkan sebagaian besar jurnal pendidikan pun dibuat dalam bahasa Inggris (Brown, 2001). Tujuan utama pengajaran reading secara umum ialah untuk mengembangkan

Cara mengutip: Triana, N. (2019). Penerapan Metode Paired Reading/ Paired Summarizing untuk Meningkatkan Kemampuan Pemahaman Membaca Teks pada Siswa SMK Abdurrab Pekanbaru. Inteligensi: Jurnal Ilmu Pendidikan, 2(1), 33-38 
kemampuan membaca siswa supaya mereka bisa mengakses informasiinformasi yang ada dan bisa mengikuti perkembangan teknologi.

Thomas (2011: 21) menyatakan bahwa membaca adalah proses aktif di mana pembaca membangun makna dari teks. Selain itu kemampuan membaca dapay meningkatkan kemampuan siswa untukk mengemukakan pendapat dengan baik, dan meningkatkan kemampuan analisis serta imajinatif (Kamhar \& Lestari, 2019: 1).

Untuk mencapai kompetensi dasar dan kompetensi standar dalam membaca, banyak strategi dapat diterapkan oleh guru untuk memaksimalkan peran mereka di kelas, tetapi kebanyakan dari mereka tidak mencoba menemukan berbagai metode dan cara apa pun untuk menjadi lebih menarik. Dimana peningkatan kualitas guru dapat menjadi kontribusi positif terhadap peningkatan prestasi siswa (Romadhon, 2019: 12). Yang berarti bagaimana guru mengarahkan pembelajaran berpusat pada siswa, sehingga guru perlu memotivasi dan memfasilitasi siswa dalam belajar bahasa Inggris.

Berdasarkan wawancara dengan para guru di SMK Abdurrab, ditemukan bahwa beberapa siswa memiliki banyak masalah dalam mengembangkan kemampuan untuk membaca yang disebabkan oleh: (1) siswa masih sulit memahami beberapa kata yang disebabkan oleh rendahnya frekuensi kegiatan membaca; (2) para siswa masih tidak mengerti tentang hubungan kata yang menentukan pemahaman membaca mereka. Beberapa siswa berpikir bahwa sebuah kata hanya memiliki makna tidak berdasarkan konteks yang pada akhirnya mempengaruhi pemahaman mereka; (3) siswa tidak dapat membaca dengan tepat terkait dengan intonasi dan akurasi. Mereka tidak tahu bahwa membaca tidak hanya untuk mendapatkan informasi tetapi juga agar dapat membaca dengan lancar; (4) kosa kata mereka terbatas, akibatnya, mereka tidak mampu membangun makna teks yang sesuai. Ini dapat dilihat dari nilai inggris siswa masih banyak yang dibawah 70.

Kualitas pembelajaran dapat menjadi lebih optimal jika dirancang sesuai dengan karakteristik dan kebutuhan siswa (Rozhana, \& Harnanik. (2019: 39). Salah satunya melalui Paired Reading/ Paired Summarizing adalah sejenis pembelajaran kooperatif. Metode ini dimaksudkan untuk mendorong berbagai jenis pemikiran, yang semuanya mendorong pemahaman. Dalam Paired Reading/ Paired Summarizing adalah teknik yang siswa pelajari secara berpasangan. Para siswa dapat belajar dan berbagi tentang sebuah teks dan mereka membuat ringkasan teks tersebut.

Menurut Crawford et al., (2005: 25)

Paired Reading / paired summarizing adalah:

"teknik untuk meminta pasangan siswa membaca teks dengan cermat untuk memahami. Paired reading / Paired summarizing menyukai semua tugas pembelajaran kooperatif, memungkinkan siswa untuk mengambil lebih banyak inisiatif dalam pembelajaran mereka sendiri dan satu sama lain".

Metode ini dimaksudkan untuk mendorong berbagai jenis pemikiran, dan pemahaman, dengan cara membaca teks dengan suara keras tiga hingga empat kali jadi untuk menghemat waktu dan guru meminta siswa membaca dengan berpasangan. Nation (2009: 67) menjelaskan bahwa membaca berpasangan adalah bentuk membaca dengan bantuan. Dalam kegiatan ini, pelajar dipasangkan 
dengan pembaca yang lebih cakap. Mereka duduk berdampingan dan membaca teks yang sama dengan lantang bersama-sama dengan kecepatan yang sama dengan pembaca yang kurang cakap. Para siswa dapat bekerja bersama dan memperbaiki kesalahan.

Thomas (2010: 100) menyatakan bahwa meringkas adalah cara pemantauan metakognitif, dimana siswa dapat mengevaluasi pemahaman mereka tentang bacaan yang mereka baca. Ini berarti bahwa seorang siswa yang belum memahami suatu teks hampir pasti mengalami kesulitan meringkasnya sehingga mereka berbagi dengan pasangannya. Dia juga berpendapat bahwa meringkas adalah perangkat yang sangat baik untuk memeriksa pemahaman. Para siswa memiliki beberapa kemampuan untuk mengidentifikasi rincian yang relevan, menggunakan isyarat struktural dan mengidentifikasi dan membangun ideide utama, mereka siap untuk jenis instruksi yang lebih formal dalam merangkum.

Tujuan utama dari penelitian ini adalah untuk mengeksplorasi apakah penggunaan Paired Reading/ Paired Summarizing memberikan efek pada pemahaman membaca siswa di SMK Abdurrab Jurusan Analisis Kesehatan Pekanbaru.

\section{METODE PENELITIAN}

Penelitian yang digunakan adalah kuasi-eksperimental dengan pretest-postest nonequivalent control group design untuk mengetahui pengaruh signifikan menggunakan Paired Reading/ Paired Summarizing pada kemampuan membaca siswa pada siswa kelas sepuluh. di SMK Abdurrab Jurusan Analisis Kesehatan Pekanbaru.

Dalam penelitian ini, dua kelas digunakan; satu kelas eksperimen dengan metode Paired Reading/ Paired Summarizing dan satu kelas kontrol diajarkan secara konvensional. Pre-test dan post-test diberikan pada pemahaman membaca siswa. Kedua kelas diberikan materi yang sama tetapi menggunakan metode pembelajaran yang berbeda. Peneliti didampingi oleh seorang pengamat, dan akhirnya, kedua kelas diberikan post-test pada akhir proses belajar-mengajar untuk menentukan efek menggunakan paired reading / paired summarizing pada pemahaman membaca siswa dan juga untuk menentukan peningkatan pemahaman membaca siswa.

\section{HASIL DAN PEMBAHASAN}

Data dari penelitian ini adalah skor pre-test dan post-test siswa dari kelas eksperimen menggunakan Paired Reading/ Paired Summarizing dan kelas kontrol menggunakan metode konvensional dengan materi ajar yang sama, dan dikumpulkan melalui prosedur test pemahaman membaca. Berikut nilai pretest membaca pada kelas percobaan yang disajikan pada tabel 1:

Tabel 1. Nilai Pre-tes Membaca pada Kelas Percobaan

\begin{tabular}{cccccc}
\hline Kategori & Nilai & Frekuensi & Persentase & $\begin{array}{c}\text { Valid } \\
\text { Persen }\end{array}$ & $\begin{array}{c}\text { Persen } \\
\text { Kumulatif }\end{array}$ \\
\hline Sangat Bagus & $80-100$ & 0 & 0 & 0 & 0 \\
Bagus & $69-79$ & 3 & 9.4 & 9.4 & 9.4 \\
Cukup & $56-68$ & 7 & 21.9 & 21.9 & 31.3 \\
Buruk & $0-55$ & 22 & 68.8 & 68.8 & 100.0 \\
Total & & 32 & 100.0 & 100.0 & \\
\hline
\end{tabular}


Tabel 1. menunjukkan hasil pre-test pada kelas percobaan sebagai berikut: jumlah siswa dengan nilai sangat baik tidak ada (0\%), jumlah siswa dengan nilai baik adalah 3 siswa $(9,4 \%)$, jumlah siswa dengan nilai cukup adalah 7 siswa $(21,9 \%)$, dan jumlah siswa dengan nilai buruk adalah 22 siswa $(68,8 \%)$. Presentase tertinggi dari klasifikasi siswa dari skor pre-tes pemahaman membaca siswa dari kelas eksperimen adalah 68,8\%. Presentasi tertinggi dari klasifikasi siswa dari skor pretes pemahaman membaca siswa dari kelas eksperimen adalah 68,8\%. Dengan demikian, mayoritas siswa di kelas eksperimen sebelum diajar dengan menggunakan Paird Reading/ Paired Summarizing dikategorikan buruk. Berikut nilai pretest membaca pada kelas kontrol:

Tabel 2. Nilai Pre-tes Membaca pada Kelas Kontrol

\begin{tabular}{cccccc}
\hline Kategori & Skor & Frekuensi & Persentase & $\begin{array}{c}\text { Valid } \\
\text { Persentase }\end{array}$ & $\begin{array}{c}\text { Persen } \\
\text { Kumulatif }\end{array}$ \\
\hline Sangat Bagus & $80-100$ & 0 & 0 & 0 & 0 \\
Bagus & $69-79$ & 2 & 6.2 & 6.2 & 8.8 \\
Cukup & $56-68$ & 7 & 21.9 & 21.9 & 38.4 \\
Buruk & $0-55$ & 23 & 71.9 & 71.9 & 100.0 \\
Total & & 32 & 100.0 & 100.0 & \\
\hline
\end{tabular}

Tabel 2. menunjukan hasil pre-test pada kelas kontrol sebagai berikut: jumlah siswa dengan nilai sangat baik tidak ada (0\%), jumlah siswa dengan nilai baik adalah 2 siswa (6,2\%), jumlah siswa dengan nilai cukup adalah 7 siswa $(21,9 \%)$, dan jumlah siswa dengan nilai buruk adalah 23 siswa (71.9\%). Dengan demikian, mayoritas siswa dikelas. kontrol sebelum diajarkan menggunakan Paird Reading/ Paired Summarizing dikategorikan buruk. Setelah dilakukan pre-test maka peneliti melanjutkan ketahap selanjutnya Pos-test pada kelas eksperimen. Adapun hasil dari posttest disajikan pada tabel 3 berikut:

Tabel 3. Nilai Post-tes Membaca pada Kelas Percobaan

\begin{tabular}{cccccc}
\hline Kategori & Nilai & Frekuensi & Persentase & $\begin{array}{c}\text { Valid } \\
\text { Persentase }\end{array}$ & $\begin{array}{c}\text { Persen } \\
\text { Kumulatif }\end{array}$ \\
\hline Sangat Bagus & $80-100$ & 10 & 29.4 & 31.3 & 31.3 \\
Bagus & $69-79$ & 12 & 35.3 & 37.5 & 68.8 \\
Cukup & $56-68$ & 8 & 23.5 & 25.0 & 93.8 \\
Buruk & $0-55$ & 2 & 5.9 & 6.3 & 100.0 \\
Total & & 32 & 100.0 & 100.0 & \\
\hline
\end{tabular}

Berdasarkan tabel 3. jumlah siswa dengan nilai sangat baik ada 10 siswa (29.4\%), nilai baik adalah 12 siswa (35.3\%), nilai cukup adalah 8 siswa $(23,5 \%)$, dan nilai buruk adalah 2 siswa $(5.9,8 \%)$. Dari data ini dapat diartikan bahwa ada peningkatan kemampuan membaca siswa dari pre-test, dimana sebagian besar siswa di kelas eksperimen setelah diajarkan dengan menggunakan Paired Reading/ Paired Summarizing diklasifikasikan sebagai baik. Selanjutnya dilakukan post-test pada kelas kontrol. Adapun hasil dari post-test disajikan pada table 4 berikut: 
Inteligensi: Jurnal Ilmu Pendidikan Vol. 2, No.1, 2019. Hal 33-38

Tabel 4. Nilai Post-test Membaca pada Kelas Kontrol

\begin{tabular}{cccccc}
\hline Kategori & Nilai & Frekuensi & Persentase & $\begin{array}{c}\text { Valid } \\
\text { Persentase }\end{array}$ & $\begin{array}{c}\text { Persen } \\
\text { Kumulatif }\end{array}$ \\
\hline Sangat Bagus & $80-100$ & 2 & 5.9 & 6.3 & 6.3 \\
Bagus & $69-79$ & 4 & 11.8 & 12.5 & 18.8 \\
Cukup & $56-68$ & 8 & 23.5 & 25.0 & 43.8 \\
Buruk & $0-55$ & 18 & 52.9 & 56.3 & 100.0 \\
Total & & 32 & 100.0 & 100.0 & \\
\hline
\end{tabular}

Berdasarkan tabel 5., menunjukkan hasil post-test pada kelas kontrol sebagai berikut: jumlah siswa dengan nilai sangat baik ada 2 siswa (5.9\%), jumlah siswa dengan nilai baik adalah 4 siswa (11.8\%), jumlah siswa dengan nilai cukup adalah 8 siswa $(23,5 \%)$, dan jumlah siswa dengan nilai buruk adalah 18 siswa (52.9,8\%). Dengan demikian, mayoritas siswa di kelas kontrol diklasifikasikan sebagai buruk.

Dari hasil penelitian ini didapatkan bahwa metode pembelajaran dengan menggunakan Paired Reading/ Paired summarizing dapat meningkatkan kemampuan pemahaman membaca bagi siswa dan bisa diaplikasikan oleh guru bahasa Inggris. Keith (2014: 57-70) menyampaikan bahwa "Paired Reading adalah cara yang menyenangkan yang dapat membantu pembaca yang kurang mampu mengembangkan keterampilan membaca yang lebih baik. Dia juga berpendapat bahwa "Metode Paired Reading (PR) untuk tutor teman sebaya atau orang tua adalah suatu bentuk membaca lisan yang yang memungkinkan siswa untuk mengakses dan memahami teks-teks beberapa tingkat diatas kemampuan.

Ponce (Khoshsima \& et.al: 2014) menyatakan bahwa "meringkas teks adalah strategi yang paling baik bagi pelajar untuk memahami sebuah teks karena Proses meringkas memfokuskan pada poin-poin utama dari teks dan memberikan pembaca kerangka kerja konseptual yang mempercepat memori dan pemahaman. Jadi metode paired reading/ summarizing merupakan metode yang tepat dan menarik dalam mengajar pemahaman membaca bagi siswa.

\section{KESIMPULAN}

Dalam mengajarkan membaca teks untuk siswa guru semestinya mencari metode yang tepat dan efisien dalam proses pembelajaran. Metode pemebelajaran Paired Reading/Paired Summarizing dapat diimplementasikan sebagai salah satu metode dalam mengajar pemehaman membaca siswa. Selain itu, kegiatan dapat diimplementasikan untuk membuat membaca lebih menyenangkan karena siswa dibimbing untuk membaca materi yang menarik dan mudah untuk menginspirasi mereka menjadi pembaca. Guru dapat menggunakan teknik ini untuk membuat siswa merasa senang dalam proses belajar mengajar. Para siswa membaca teks secara berpasangan, mereka dapat menemukan informasi bersama dan mereka dapat berbagi dan bekerja bersama dengan pasangan mereka. Akhirnya, Paired Reading/ Paired Summarizing adalah salah satu teknik yang dapat dianggap sebagai cara yang baik untuk memahami pemahaman membaca.

\section{DAFTAR PUSTAKA}

Brown, H. D. (2001). Teaching by Principles an Interactive Approach to 
Language Pedagogy (2nd ed). San Francisco: Wesley Longman, Inc.

Crawford, A., Saul, E. W., \& Makinster, J. (2005). Teaching and Learning Strategies for the Thinking Classroom. New York: The International Education Assosiation.

Kamhar, M.Y., \& Lestari, E. (2019). Pemanfaat Sosial Media Youtube Sebagai Media Pembelajaran Bahasa Indonesia DI Perguruan Tinggi. Jurnal Inteligensi: Ilmu Pendidikan, UNITRI Press. 1(2), 1-7. http://dx.doi.org/10.33366/ilg.v1i2.1 356

Keith, J. T. (2014). Paired Reading and Related Methods for Improving Fluency. Journal of Elementary Education, 7(1), 57-70.

Khoshsima, H \& Rezaeian, T. (2014). Forouzan. The effect of summarizing strategy on reading comprehension of Iranian intermediate EFL learners. International Journal of Language and Linguistics. 2(3), 2014. pp.134139. doi.10.11648/j.ij1l.20140203.11 Nation. I. S. P. (2009). Teaching ESL/EFL Reading and Writing. New York. Mad Ave.

Romadhon. (2019). Peran Kepala Sekolah Sebagai Manager Dalam Menciptakan Sekolah Efektif di SMP An-Nur Bululawang Malang. Jurnal Inteligensi: Ilmu Pendidikan, UNITRI Press. 1(2), 8-15.

Rozhana, K.M., \& Harnanik. (2019). Lesson Study dengan Metode Discovery Learning dan Problem Based Instruction. Jurnal Inteligensi: Ilmu Pendidikan, UNITRI Press. 1(2), 39-45. http://dx.doi.org/10.33366/ilg.v1i2.1 355

Thomas, G. (2010). Creating Literacy Instruction for All students in Grades 4-8 (3rd ed.). Boston: Pearson Education, Inc. 